\title{
Fox Serum Proteomics Analysis Suggests Host-Specific Responses to Angiostrongylus vasorum Infection in Canids
}

\author{
Nina Gillis-Germitsch ${ }^{1,2}$, Tobias Kockmann ${ }^{3}$, Christian M. O. Kapel ${ }^{4}$, Stig M. Thamsborg ${ }^{5}$, Pia Webster ${ }^{5,6}$, \\ Lucienne Tritten ${ }^{1, * \mathbb{D}}$ and Manuela Schnyder ${ }^{1, * \mathbb{D}}$ \\ 1 Institute of Parasitology, Vetsuisse Faculty, University of Zurich, Winterthurerstrasse 266a, \\ 8057 Zurich, Switzerland; nina.gillis-germitsch2@uzh.ch \\ 2 Graduate School for Cellular and Biomedical Sciences, University of Bern, Mittelstrasse 43, \\ 3012 Bern, Switzerland \\ 3 Functional Genomics Center Zurich, Swiss Federal Institute of Technology Zurich (ETH Zurich), \\ University of Zurich, Winterthurerstrasse 190, 8057 Zurich, Switzerland; tobias.kockmann@fgcz.ethz.ch \\ 4 Section for Organismal Biology, Department of Plant and Environmental Sciences, University of Copenhagen, \\ Thorvaldsensvej 40, 1871 Frederiksberg C, Denmark; chk@plen.ku.dk \\ 5 Veterinary Parasitology Research Group, Department of Veterinary and Animal Sciences, \\ University of Copenhagen, Dyrlægevej 100, 1870 Frederiksberg C, Denmark; smt@sund.ku.dk (S.M.T.); \\ PIW@ssi.dk (P.W.) \\ 6 Prediagnostics and Service, Infectious Disease Preparedness, Statens Serum Institut, Artillerivej 5, \\ 2300 Copenhagen S, Denmark \\ * Correspondence: lucienne.tritten@uzh.ch (L.T.); manuela.schnyder@uzh.ch (M.S.); \\ Tel.: +41-44-635-85-01 (L.T. \& M.S.); Fax: +41-44-635-89-07 (L.T. \& M.S.)
}

Citation: Gillis-Germitsch, N.; Kockmann, T.; Kapel, C.M.O.; Thamsborg, S.M.; Webster, P.; Tritten, L.; Schnyder, M. Fox Serum Proteomics Analysis Suggests Host-Specific Responses to Angiostrongylus vasorum Infection in Canids. Pathogens 2021, 10, 1513. https://doi.org/10.3390/ pathogens 10111513

Academic Editor: Maria Filippa Addis

Received: 4 October 2021

Accepted: 17 November 2021

Published: 19 November 2021

Publisher's Note: MDPI stays neutral with regard to jurisdictional claims in published maps and institutional affiliations.

Copyright: (c) 2021 by the authors. Licensee MDPI, Basel, Switzerland. This article is an open access article distributed under the terms and conditions of the Creative Commons Attribution (CC BY) license (https:// creativecommons.org/licenses/by/ $4.0 /)$.
Abstract: Dogs infected with the cardiopulmonary nematode Angiostrongylus vasorum may suffer from respiratory distress and/or bleeding disorders. Descriptions of clinical signs in foxes are rare, despite high prevalence. To evaluate the impact of infection on coagulation and immune response, serum proteins from eight experimentally infected foxes before and after inoculation (day 0, 35, 84, 154) were subjected to differential proteomic analyses based on quantitative data and compared to available data from dogs. The number of proteins with differential abundance compared to the uninfected baseline increased with chronicity of infection. Bone marrow proteoglycan, chitinase 3-like protein 1 and pulmonary surfactant-associated protein B were among the most prominently increased proteins. The abundance of several proteins involved in coagulation was decreased. Enriched pathways obtained from both increased and decreased proteins included, among others, "platelet degranulation" and "haemostasis", and indicated both activation and suppression of coagulation. Qualitative comparison to dog data suggests some parallel serum proteomic alterations. The comparison, however, also indicates that foxes have a more adequate immunopathological response to A. vasorum infection compared to dogs, facilitating persistent infections in foxes. Our findings imply that foxes may be more tolerant to $A$. vasorum infection, as compared to dogs, reflecting a longer evolutionary host-parasite adaptation in foxes, which constitute a key wildlife reservoir.

Keywords: Angiostrongylus vasorum; proteomics; fox; Vulpes vulpes; immune response; coagulation

\section{Introduction}

Angiostrongylus vasorum is a cardiopulmonary nematode of canids. Adults reside in the right side of the heart of the definitive hosts, where females release numerous eggs. First-stage larvae (L1) hatch and migrate through the lung where they cause tissue damage and pneumonia. First-stage larvae are eventually coughed up, swallowed, and excreted with the faeces. Slugs and snails act as intermediate hosts, in which L1 develop to infectious third-stage larvae (L3). Canids are infected by the ingestion of L3 contained in gastropod intermediate hosts, which then migrate to the heart where they further develop [1]. Angiostrongylus vasorum is endemic in Europe and parts of North and South America [2-4]. In 
Europe, incidence rates in dogs and prevalence in foxes increased in the last few decades in countries where $A$. vasorum has been present for many years [5-7] and, simultaneously, has been increasingly detected in areas where it has not been reported before [8-10]. In the domestic cycle, the main definitive hosts are dogs (Canis lupus familiaris). In Europe, foxes (Vulpes vulpes) serve as the most important reservoir host, but depending on the geographical region, other wild canids such as coyotes (Canis latrans) [11], crab-eating foxes (Cerdocyon thous) [12], hoary foxes (Dusicyon vetulus) [13] or wolves (Canis lupus) [14] and other animals such as red pandas (Ailurus fulgens fulgens) [15], badgers (Meles meles) [16], and meerkats (Suricata suricatta) [17] may serve as definitive hosts.

The clinical picture of canine angiostrongylosis is broad and highly variable $[2,18]$. Infected dogs may suffer respiratory distress with, e.g., coughing and dyspnoea [19], bleeding disorders, which manifest in internal or external bleeding [20-22], or may show neurological signs due to haemorrhages in the central nervous system [23]. In foxes, clinical signs are rarely described [24,25], and experimental infections with 50 or 200 L3 did not lead to clinical illness [26,27]. However, diagnostic imaging and post mortem investigations of infected dogs and foxes indicated severe lung pathologies in both species $[5,19,28-31]$. Today, the differences in clinical manifestations and in the host-parasite interactions between A. vasorum infected dogs and foxes remain largely unstudied and poorly understood. A limited number of studies with a focus on the immune response or coagulation status have been conducted in dogs $[19,22,32,33]$. To improve our understanding of the host-parasite interplay between foxes and $A$. vasorum, and to assess whether serum protein alterations observed in $A$. vasorum-infected foxes are host-specific, we performed fox serum proteome analysis using experimental samples and compared the data to those reported recently in dogs [32].

\section{Results}

Serum samples from eight $A$. vasorum experimentally infected foxes were drawn at four different time points (right before inoculation (d0), and during prepatency (d35), patency (d84) and the chronic stage of infection (d154, 5 foxes only)) and analysed by nano liquid chromatography coupled to mass spectrometry (LC-MS) to monitor the compositional changes of the blood proteome in response to parasite infection. In total, 751 proteins were identified and quantified across all analysed samples (Supplementary Figure S1), 4 of which were identified as $A$. vasorum proteins.

\subsection{Differentially Abundant Proteins}

Overall, 276 proteins showed significant abundance increase or decrease ( $\log 2$ fold change $(\mathrm{FC}) \geq 1 / \leq-1$, adjusted $p$-value $\leq 0.05$ ) with respect to d0. Among them were two A. vasorum proteins, which were excluded from further analysis. A detailed list of all significantly increased or decreased proteins at all time point comparisons, including $\log 2$ FC and adjusted $p$-values, can be found in Supplementary Table S1. Compared to before infection (d0), levels of 29 proteins were increased at $\mathrm{d} 35$, while 19 were decreased. At d84, compared to before infection (d0), the abundance of 65 proteins was increased and the abundance of 32 proteins decreased. Of these, 40 and 20 proteins were not significantly altered earlier, at $\mathrm{d} 35$, and therefore, additionally increased and decreased, respectively. One hundred fifty-four days after inoculation, 93 proteins were increased and 82 were decreased compared to d0 (Figure 1a). Among increased and decreased proteins, 48 and 57 proteins had not been significantly altered at previous time points, respectively. Comparing $\mathrm{d} 84$ to $\mathrm{d} 35$, the abundance of 17 proteins had either increased (12) or decreased (5), and comparing d 154 to d 35 , levels of 140 proteins ( 88 and 52, respectively) were changed. Comparing d154 to $\mathrm{d} 85$, the abundance of 42 proteins had increased (16) or decreased (26). 
(a)

d35 vs. d0

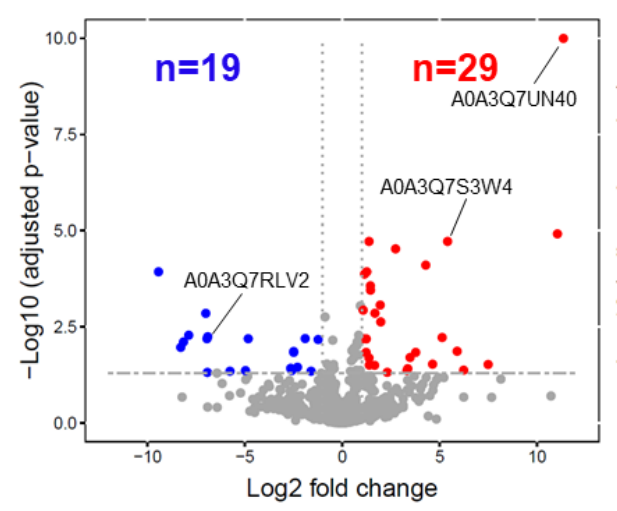

No change

Decreased
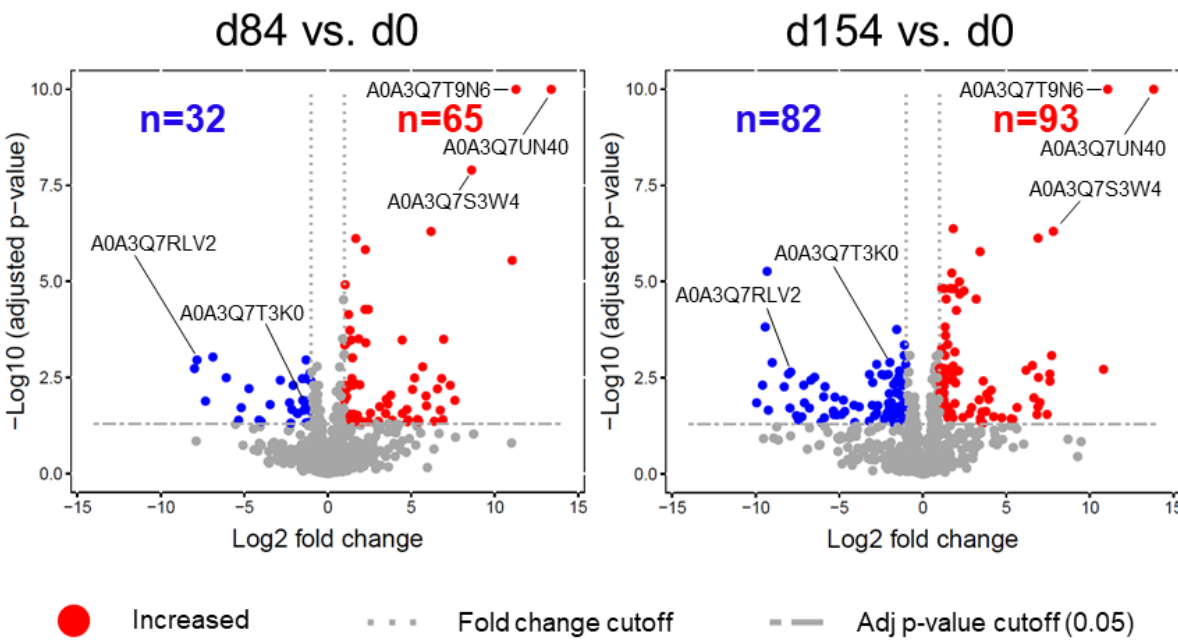

(b)
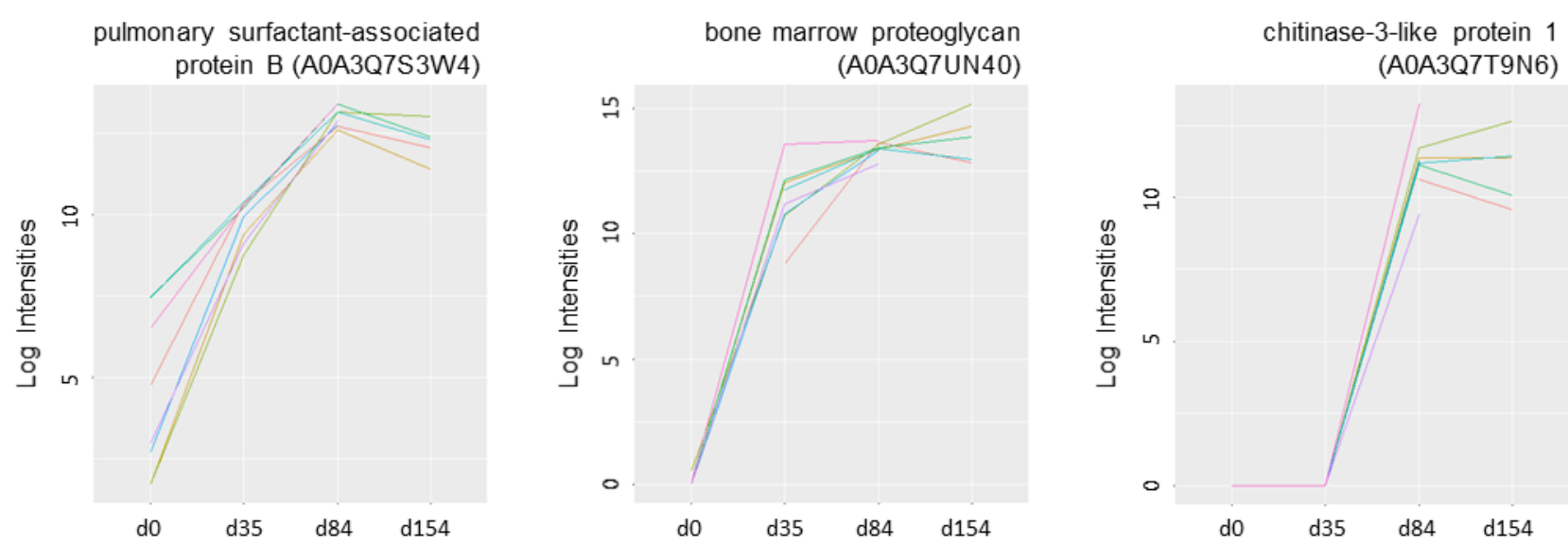

vitamin $\mathrm{K}$-dependent protein $\mathrm{C}$ (A0A3Q7T3K0;A0A3Q7TP28;A 0A3Q7U1H9;A0A3Q7UE75)
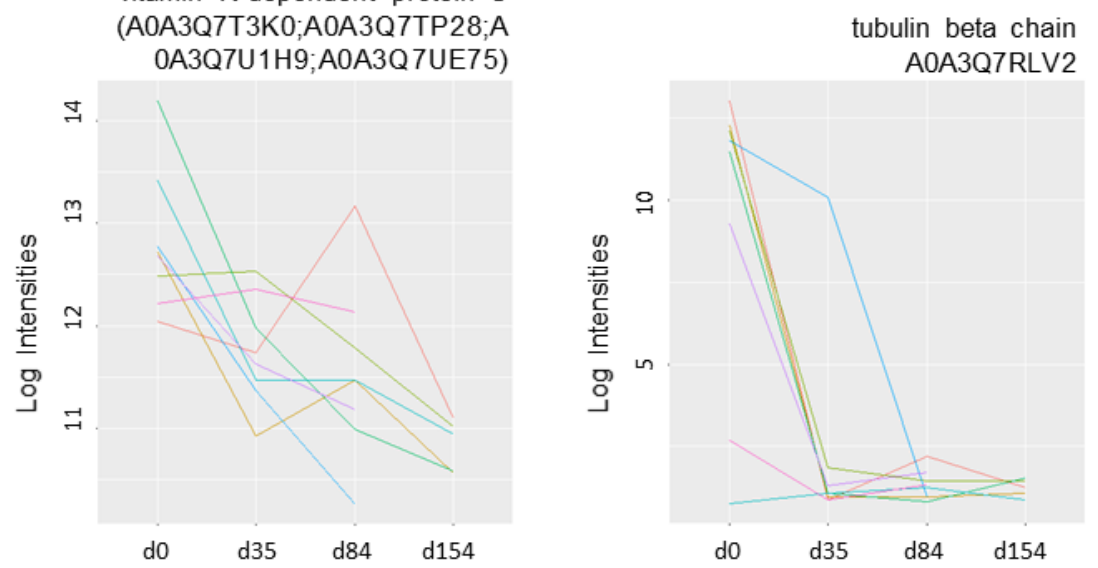

Figure 1. (a) Volcano plots of significantly increased and decreased fox serum proteins (fold change cut-off $\geq 1$, or $\leq-1$ ) of up to 8 Angiostrongylus vasorum experimentally infected animals. Three time points of infection (d35, d84, d154) were compared to before infection ( $\mathrm{d} 0$ ). (b) Individual profile plots for selected serum proteins of infected foxes: pulmonary surfactant-associated protein B (A0A3Q7S3W4), bone marrow proteoglycan (A0A3Q7UN40), chitinase-3-like protein 1 (A0A3Q7T9N6), vitamin K-dependent protein C (A0A3Q7T3K0; A0A3Q7TP28; A0A3Q7U1H9; A0A3Q7UE75), and tubulin beta chain (A0A3Q7RLV2). On the $x$ axis are the time points $\mathrm{d} 0, \mathrm{~d} 35, \mathrm{~d} 84$, and $\mathrm{d} 154$, and $\log 2$ protein intensities are listed on the $y$ axis. 
The most strongly increased protein across all time point comparisons was bone marrow proteoglycan (A0A3Q7UN40; FC: 11.4-13.8). Other significantly and highly increased proteins as of $\mathrm{d} 85$ (compared to before infection) were chitinase-3-like protein 1 (A0A3Q7T9N6), pulmonary surfactant-associated protein B (A0A3Q7S3W4), and interleukin enhancer-binding factor 2 (A0A3Q7SCP6; A0A3Q7TCE1). Further significantly increased proteins involved in immune response, inflammation or coagulation included, among others, fibrinogen alpha and beta chains (A0A3Q7T5Z6/A0A3Q7TRK4), fibulin 2 and 5 (A0A3Q7RP65; A0A3Q7SXX8/A0A3Q7R7A1), thrombospondin 1 and 3 (A0A3Q7SDJ4/A0A3Q7SAF2), and eosinophil peroxidase (A0A3Q7S7C1). Among the most decreased proteins were tubulin beta chain proteins (A0A3Q7UCJ4/A0A3Q7RLV2), LIM and senescent cell antigen-like-containing domain protein (A0A3Q7TMY6; A0A3Q7UH09), beta-parvin (A0A3Q7U5D8), and integrin-linked protein kinase (A0A3Q7RAD1). Further significantly decreased proteins involved in immune response, inflammation or coagulation included coagulation factor XIII A chain (A0A3Q7RD39), vitamin K-dependent protein C (A0A3Q7T3K0; A0A3Q7TP28; A0A3Q7U1H9; A0A3Q7UE75), macrophage migration inhibitory factor (A0A3Q7QZI1), coagulation factor X (A0A3Q7SQ30), and coagulation factor IX (A0A3Q7UBG7). Changes were mostly consistent across all eight foxes. Figure $1 \mathrm{~b}$ displays five examples.

\subsection{Gene Ontology and Pathway Enrichment}

Tables 1 and 2 display the top 10 gene ontology biological processes and significantly enriched pathways for each time point comparison to before infection (d0) resulting from increased or decreased proteins, respectively. All significant biological processes and enriched pathways from either increased or decreased proteins are listed in Supplementary Table S2.

Among the top 10 biological processes resulting from significantly increased proteins (adjusted $p$-value $\leq 0.05$ ) in infected foxes compared to uninfected baseline, considering all time point comparisons combined, were "neutrophil mediated immunity" (GO:0002446), "neutrophil activation involved in immune response" (GO:0002283), "neutrophil degranulation" (GO:0043312), and "extracellular matrix organization" (GO:0030198). Further biological processes resulting from GO enrichment from both increased and decreased protein sets were, e.g., "platelet degranulation" (GO:0002576), "plasminogen activation" (GO:0031639), and "positive regulation of coagulation" (GO:0050820).

Among enriched pathways resulting from gene set enrichment analysis based on increased proteins (all time points combined) were "extracellular matrix organization", "platelet degranulation", "formation of fibrin clot (clotting cascade)", "platelet activation, signalling and aggregation", and "haemostasis". "Platelet degranulation", "response to elevated platelet cytosolic $\mathrm{Ca}^{2+1}$, "intrinsic pathway of fibrin clot formation", and "haemostasis" were among enriched pathways obtained from decreased proteins. 


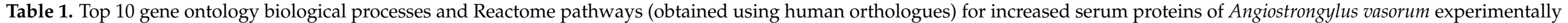
infected foxes in time point comparisons.

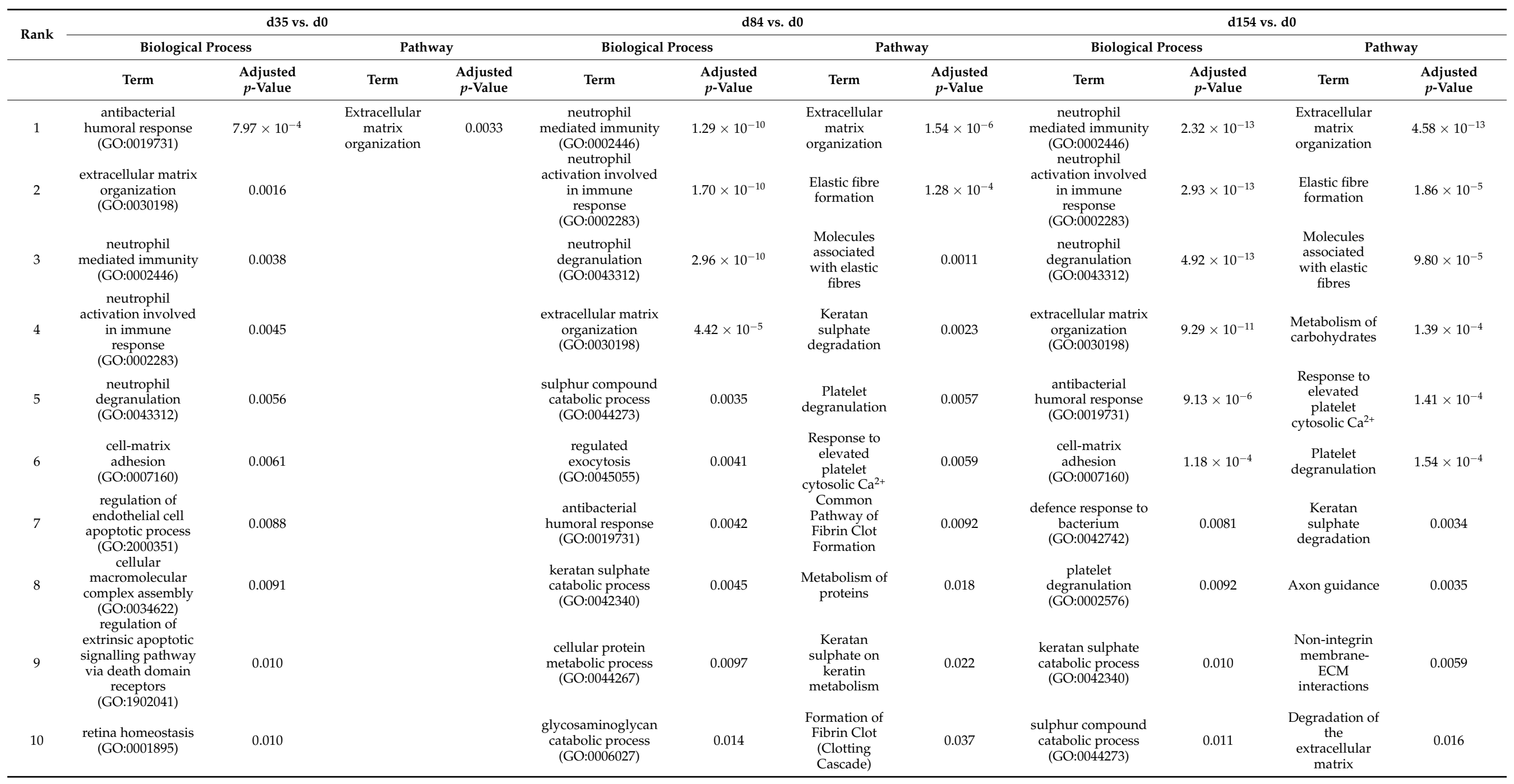




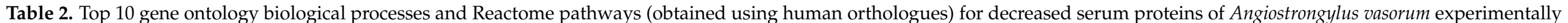
infected foxes in time point comparisons.

\begin{tabular}{|c|c|c|c|c|c|c|c|c|c|c|c|c|}
\hline \multirow{3}{*}{ Rank } & \multicolumn{4}{|c|}{ d35 vs. d0 } & \multicolumn{4}{|c|}{ d84 vs. d0 } & \multicolumn{4}{|c|}{ d154 vs. d0 } \\
\hline & \multicolumn{2}{|c|}{ Biological Process } & \multicolumn{2}{|c|}{ Pathway } & \multicolumn{2}{|c|}{ Biological Process } & \multicolumn{2}{|c|}{ Pathway } & \multicolumn{2}{|c|}{ Biological Process } & \multicolumn{2}{|c|}{ Pathway } \\
\hline & Term & $\begin{array}{c}\text { Adjusted } \\
p \text {-Value }\end{array}$ & Term & $\begin{array}{c}\text { Adjusted } \\
p \text {-Value }\end{array}$ & Term & $\begin{array}{c}\text { Adjusted } \\
p \text {-Value }\end{array}$ & Term & $\begin{array}{c}\text { Adjusted } \\
p \text {-Value }\end{array}$ & Term & $\begin{array}{c}\text { Adjusted } \\
p \text {-Value }\end{array}$ & Term & $\begin{array}{c}\text { Adjusted } \\
p \text {-Value }\end{array}$ \\
\hline 1 & $\begin{array}{l}\text { positive regulation of } \\
\text { establishment of } \\
\text { protein localization to } \\
\text { telomere (GO:1904851) }\end{array}$ & $7.26 \times 10^{-5}$ & $\begin{array}{l}\text { Prefoldin mediated } \\
\text { transfer of substrate } \\
\text { to CCT /TriC }\end{array}$ & $3.12 \times 10^{-11}$ & $\begin{array}{l}\text { positive regulation } \\
\text { of establishment of } \\
\text { protein localization } \\
\text { to telomere } \\
\text { (GO:1904851) }\end{array}$ & $4.79 \times 10^{-4}$ & $\begin{array}{c}\text { Prefoldin } \\
\text { mediated transfer } \\
\text { of substrate to } \\
\text { CCT / TriC }\end{array}$ & $6.89 \times 10^{-12}$ & $\begin{array}{l}\text { regulation of } \\
\text { protein localization } \\
\text { to Cajal body } \\
\text { (GO:1904869) }\end{array}$ & $3.05 \times 10^{-5}$ & $\begin{array}{c}\text { Prefoldin } \\
\text { mediated transfer } \\
\text { of substrate to } \\
\text { CCT } / \text { TriC }\end{array}$ & $4.54 \times 10^{-9}$ \\
\hline 2 & $\begin{array}{l}\text { regulation of protein } \\
\text { localization to Cajal } \\
\text { body (GO:1904869) }\end{array}$ & $7.27 \times 10^{-5}$ & $\begin{array}{c}\text { Formation of } \\
\text { tubulin folding } \\
\text { intermediates by } \\
\text { CCT/TriC }\end{array}$ & $3.74 \times 10^{-11}$ & $\begin{array}{l}\text { regulation of } \\
\text { protein localization } \\
\text { to Cajal body } \\
\text { (GO:1904869) }\end{array}$ & $4.79 \times 10^{-4}$ & $\begin{array}{c}\text { Formation of } \\
\text { tubulin folding } \\
\text { intermediates by } \\
\text { CCT/TriC }\end{array}$ & $7.48 \times 10^{-12}$ & $\begin{array}{l}\text { positive regulation } \\
\text { of protein } \\
\text { localization to Cajal } \\
\text { body (GO:1904871) }\end{array}$ & $6.10 \times 10^{-5}$ & $\begin{array}{c}\text { Formation of } \\
\text { tubulin folding } \\
\text { intermediates by } \\
\text { CCT } / \text { TriC }\end{array}$ & $4.95 \times 10^{-9}$ \\
\hline 3 & $\begin{array}{c}\text { regulation of } \\
\text { establishment of } \\
\text { protein localization to } \\
\text { telomere } \\
\text { (GO:0070203) }\end{array}$ & $7.78 \times 10^{-5}$ & $\begin{array}{l}\text { Cooperation of } \\
\text { Prefoldin and } \\
\text { TriC/CCT in actin } \\
\text { and tubulin folding }\end{array}$ & $6.36 \times 10^{-11}$ & $\begin{array}{l}\text { regulation of } \\
\text { establishment of } \\
\text { protein localization } \\
\text { to telomere } \\
\text { (GO:0070203) }\end{array}$ & $5.12 \times 10^{-4}$ & $\begin{array}{l}\text { Cooperation of } \\
\text { Prefoldin and } \\
\text { TriC/CCT in actin } \\
\text { and tubulin } \\
\text { folding }\end{array}$ & $1.73 \times 10^{-11}$ & $\begin{array}{l}\text { positive regulation } \\
\text { of telomerase RNA } \\
\text { localization to Cajal } \\
\text { body (GO:1904874) }\end{array}$ & $3.89 \times 10^{-4}$ & Haemostasis & $6.69 \times 10^{-9}$ \\
\hline 4 & $\begin{array}{l}\text { positive regulation of } \\
\text { protein localization to } \\
\text { chromosome, } \\
\text { telomeric region } \\
\text { (GO:1904816) }\end{array}$ & $8.55 \times 10^{-5}$ & $\begin{array}{l}\text { Chaperonin- } \\
\text { mediated protein } \\
\text { folding }\end{array}$ & $4.44 \times 10^{-8}$ & $\begin{array}{l}\text { positive regulation } \\
\text { of protein } \\
\text { localization to } \\
\text { chromosome, } \\
\text { telomeric region } \\
\text { (GO:1904816) }\end{array}$ & $5.63 \times 10^{-4}$ & $\begin{array}{l}\text { Chaperonin- } \\
\text { mediated protein } \\
\text { folding }\end{array}$ & $3.99 \times 10^{-8}$ & $\begin{array}{c}\text { regulation of } \\
\text { telomerase RNA } \\
\text { localization to Cajal } \\
\text { body (GO:1904872) }\end{array}$ & $4.32 \times 10^{-4}$ & $\begin{array}{l}\text { Cooperation of } \\
\text { Prefoldin and } \\
\text { TriC/CCT in actin } \\
\text { and tubulin } \\
\text { folding }\end{array}$ & $8.48 \times 10^{-9}$ \\
\hline 5 & $\begin{array}{l}\text { positive regulation of } \\
\text { establishment of } \\
\text { protein localization } \\
\text { (GO:1904951) }\end{array}$ & $9.50 \times 10^{-5}$ & Protein folding & $5.17 \times 10^{-8}$ & $\begin{array}{l}\text { positive regulation } \\
\text { of establishment of } \\
\text { protein localization } \\
\text { (GO:1904951) }\end{array}$ & $6.25 \times 10^{-4}$ & Protein folding & $4.94 \times 10^{-8}$ & $\begin{array}{l}\text { positive regulation } \\
\text { of protein } \\
\text { localization to } \\
\text { nucleus } \\
\text { (GO:1900182) }\end{array}$ & $4.72 \times 10^{-4}$ & $\begin{array}{l}\text { Folding of actin by } \\
\text { CCT/TriC }\end{array}$ & $1.09 \times 10^{-5}$ \\
\hline 6 & $\begin{array}{l}\text { positive regulation of } \\
\text { protein localization to } \\
\text { Cajal body } \\
\text { (GO:1904871) }\end{array}$ & $1.45 \times 10^{-4}$ & $\begin{array}{l}\text { Folding of actin by } \\
\text { CCT/TriC }\end{array}$ & $1.55 \times 10^{-5}$ & $\begin{array}{l}\text { positive regulation } \\
\text { of protein } \\
\text { localization to Cajal } \\
\text { body (GO:1904871) }\end{array}$ & $9.58 \times 10^{-4}$ & $\begin{array}{l}\text { Post-chaperonin } \\
\text { tubulin folding } \\
\text { pathway }\end{array}$ & $8.64 \times 10^{-6}$ & $\begin{array}{c}\text { platelet } \\
\text { degranulation } \\
\text { (GO:0002576) }\end{array}$ & $4.83 \times 10^{-4}$ & $\begin{array}{l}\text { Chaperonin- } \\
\text { mediated protein } \\
\text { folding }\end{array}$ & $1.54 \times 10^{-5}$ \\
\hline 7 & $\begin{array}{l}\text { positive regulation of } \\
\text { telomerase RNA } \\
\text { localization to Cajal } \\
\text { body (GO:1904874) }\end{array}$ & $1.68 \times 10^{-4}$ & $\begin{array}{l}\text { Cell-extracellular } \\
\text { matrix interactions }\end{array}$ & $6.20 \times 10^{-5}$ & $\begin{array}{l}\text { positive regulation } \\
\text { of telomerase RNA } \\
\text { localization to Cajal } \\
\text { body (GO:1904874) }\end{array}$ & 0.0011 & $\begin{array}{l}\text { Folding of actin by } \\
\text { CCT/TriC }\end{array}$ & $8.78 \times 10^{-5}$ & $\begin{array}{c}\text { regulation of } \\
\text { lipoprotein lipase } \\
\text { activity } \\
\text { (GO:0051004) }\end{array}$ & $5.10 \times 10^{-4}$ & Protein folding & $2.02 \times 10^{-5}$ \\
\hline 8 & $\begin{array}{l}\text { regulation of } \\
\text { telomerase RNA } \\
\text { localization to Cajal } \\
\text { body (GO:1904872) }\end{array}$ & $2.63 \times 10^{-4}$ & $\begin{array}{l}\text { Post-chaperonin } \\
\text { tubulin folding } \\
\text { pathway }\end{array}$ & $1.49 \times 10^{-4}$ & $\begin{array}{l}\text { regulation of } \\
\text { telomerase RNA } \\
\text { localization to Cajal } \\
\text { body (GO:1904872) }\end{array}$ & 0.0017 & $\begin{array}{l}\text { Cell-extracellular } \\
\text { matrix interactions }\end{array}$ & $3.56 \times 10^{-4}$ & $\begin{array}{c}\text { hydrogen peroxide } \\
\text { metabolic process } \\
\text { (GO:0042743) }\end{array}$ & $5.83 \times 10^{-4}$ & $\begin{array}{c}\text { Platelet } \\
\text { degranulation }\end{array}$ & $2.32 \times 10^{-5}$ \\
\hline 9 & $\begin{array}{l}\text { positive regulation of } \\
\text { telomere maintenance } \\
\text { via telomerase } \\
\text { (GO:0032212) }\end{array}$ & 0.0014 & $\begin{array}{l}\text { Association of } \\
\text { TriC/CCT with } \\
\text { target proteins } \\
\text { during biosynthesis }\end{array}$ & $7.78 \times 10^{-4}$ & $\begin{array}{l}\text { regulation of } \\
\text { lipoprotein lipase } \\
\text { activity } \\
\text { (GO:0051004) }\end{array}$ & 0.0021 & $\begin{array}{c}\text { Platelet } \\
\text { degranulation }\end{array}$ & 0.0034 & $\begin{array}{c}\text { regulated } \\
\text { exocytosis } \\
\text { (GO:0045055) }\end{array}$ & $7.10 \times 10^{-4}$ & $\begin{array}{l}\text { Response to } \\
\text { elevated platelet } \\
\text { cytosolic } \mathrm{Ca}^{2+}\end{array}$ & $2.84 \times 10^{-5}$ \\
\hline 10 & $\begin{array}{l}\text { positive regulation of } \\
\text { telomere maintenance } \\
\text { via telomere } \\
\text { lengthening } \\
\text { (GO:1904358) }\end{array}$ & 0.0015 & $\begin{array}{l}\text { Cooperation of } \\
\text { PDCL (PhLP1) and } \\
\text { TRiC/CCT in } \\
\text { G-protein beta } \\
\text { folding }\end{array}$ & $8.78 \times 10^{-4}$ & $\begin{array}{l}\text { acylglycerol } \\
\text { homeostasis } \\
\text { (GO:0055090) }\end{array}$ & 0.0026 & $\begin{array}{l}\text { Response to } \\
\text { elevated platelet } \\
\text { cytosolic } \mathrm{Ca}^{2+}\end{array}$ & 0.0037 & $\begin{array}{l}\text { chylomicron } \\
\text { remodelling } \\
\text { (GO:0034371) }\end{array}$ & 0.0019 & $\begin{array}{l}\text { Cell-extracellular } \\
\text { matrix interactions }\end{array}$ & $4.23 \times 10^{-5}$ \\
\hline
\end{tabular}




\subsection{Qualitative Comparison of Serum Alterations of A. vasorum Experimentally Infected Foxes and Dogs}

Significantly increased or decreased fox serum proteins were qualitatively compared to those found in an experimental dog infection model, where comparable time points were examined, i.e., d-7, d34, d75, d104, and d230 [32]. Applying the same cut-off at adjusted $p$-value $\leq 0.05$ and $\log 2 \mathrm{FC} \geq 1$, or $\leq-1$, foxes had a larger number of increased or decreased proteins at each time point compared to dogs. Bone marrow proteoglycan, the most prominently increased protein in fox samples at each time point after onset of infection, was not increased in dogs. At day 35, both dogs and foxes showed increased abundance of pulmonary surfactant-associated protein B, polymeric immunoglobulin receptor, and CD5 antigen-like protein. At d75, the most strongly increased protein in dogs was chitinase 3-like protein 1, which was the second most prominently increased protein in foxes at $\mathrm{d} 84$. At the same time point, pulmonary surfactant-associated protein $\mathrm{B}$ was the second most strongly increased protein in dogs and the fourth most strongly increased in foxes. Other proteins with increasing abundance over the course of infection common in both species at $\mathrm{d} 84 \mathrm{vs.} \mathrm{d} 0$ (foxes) or d75 vs. d-7 (dogs) were, among others, fibulin 2, interleukin enhancer-binding factor 2, prosaposin, and phosphoglycerate mutase (Figure 2). Chitinase 3-like protein 1 remained the most prominently increased protein at later time points in dogs and remained the second most increased protein at d154 in foxes. The same applies for pulmonary surfactant-associated protein B, which stayed the second most strongly increased in dogs and the fourth most prominently increased in foxes at the chronic stage of infection. Fibulin 2 abundance remained increased until the end of the experiment in both species, and phosphoglycerate mutase abundance only in foxes. The von Willebrand factor type A level was increased in both dogs and foxes at d230 and d154, respectively. In dogs, this protein had already been increased at $\mathrm{d} 75$, but not in foxes (d84). In dogs, levels of several Ig-like domain-containing proteins were increased over the course of infection, and coagulation factor VIII at d230, while these were not increased in foxes at any time points.

Among proteins at $\mathrm{d} 35$ and $\mathrm{d} 34$ compared to pre-infection, dogs and foxes had no decreased proteins in common. When comparing d84 vs. $d 0$ in foxes with d75 vs. d-7 in dogs, the only decreased proteins present in both species were coagulation factor XIII (A chain in the fox and B chain in the dog) and histidine-rich glycoprotein (Figure 2). Comparing later time points to uninfected baseline (d104 vs. d-7 and d230 vs. d-7 for dogs and $\mathrm{d} 154$ vs. $\mathrm{d} 0$ for foxes), the only common decreased proteins were coagulation factor $\mathrm{X}$, attractin, histidine rich glycoprotein, and adiponectin. Dogs had several decreased mannan binding lectin serine peptidases as of day 34 after infection; in foxes, mannan binding lectin serine peptidase 2 abundance was increased at $\mathrm{d} 84$ vs. $\mathrm{d} 0$ (Figure 2). Further dog serum proteins that were decreased at several time points but increased in foxes as of day 35 were thrombospondins and fibrinogen chains. 


\begin{tabular}{|c|c|c|c|}
\hline $\begin{array}{l}\text { increased } \\
\text { proteins }\end{array}$ & $\begin{array}{l}\text { Bone marrow proteoglycan } \\
\text { 5-oxoprolinase } \\
\text { Anion exchange protein } \\
\text { Eosinophil peroxidase } \\
\text { Interleukin enhancer-binding factor } 3 \\
\text { Fibrinogen alpha and beta chain } \\
\text { Sushi domain-containing protein } 2 \\
\text { Fibulin-5 } \\
\text { Thrombospondin-1 } \\
\text { Mannan binding lectin serine peptidase } 2 \\
\text { Platelet basic protein-like }\end{array}$ & $\begin{array}{l}\text { Chitinase-3-like protein } 1 \\
\text { Pulmonary surfactant-associated protein B } \\
\text { Interleukin enhancer-binding factor } 2 \\
\text { Phosphoglycerate mutase } \\
\text { Fibulin-2 } \\
\text { Arachidonate 15-lipoxygenase } \\
\text { Polymeric immunoglobulin receptor } \\
\text { Napsin-A } \\
\text { Prosaposin }\end{array}$ & $\begin{array}{l}\text { Heat shock protein family A (Hsp70) } \\
\text { Apolipoprotein B } \\
\text { Apolipoprotein E } \\
\text { Sushi, von Willebrand factor type A, EGF and } \\
\text { pentraxin domain containing } 1 \\
\text { Prosaposin } \\
\text { Ig-like domain-containing protein } \\
\text { Lymphocyte cytosolic protein } 1\end{array}$ \\
\hline decreased & $\begin{array}{l}\text { Tubulin alpha and beta chain } \\
\text { LIM and senescent cell } \\
\quad \text { antigen-like-containing domain protein } \\
\text { Angiopoietin-like protein } 8 \\
\text { Cytokine receptor-like factor } 3 \\
\text { Apolipoprotein C-III } \\
\text { Vitamin K-dependent protein C } \\
\text { Neutrophil cytosol factor } 2\end{array}$ & $\begin{array}{l}\text { Histidine-rich glycoprotein } \\
\text { Coagulation factor XIII A or B chain }\end{array}$ & $\begin{array}{l}\text { ADAM metallopeptidase with } \\
\text { thrombospondin } \\
\text { Coagulation factor } \mathrm{V} \\
\text { Mannan binding lectin serine peptidase } 1 \\
\text { Mannan binding lectin serine peptidase } 2 \\
\text { Fibrinogen beta chain }\end{array}$ \\
\hline
\end{tabular}

Figure 2. Comparison of abundant common and diverging increased and decreased serum proteins involved in immune response, inflammation, or coagulation of Angiostrongylus vasorum experimentally infected foxes and dogs at d84 vs. d0 and d75 vs. d-7, respectively (the overall number of in- or decreased proteins at this time point comparison are encircled). Dog data was obtained from Tritten et al. [32]. This figure was created using BioRender.com.

\section{Discussion}

Little is known about the effect of $A$. vasorum infection on foxes despite their important role as wildlife reservoir hosts [5]. The goal of this study was to identify serum alterations over time in foxes experimentally infected with $A$. vasorum to generate a deeper understanding of the host-parasite interaction between foxes and $A$. vasorum. A similar analysis over the course of $A$. vasorum infection has already proven useful to better understand the pathogenesis in dogs [32]. This allowed emphasizing differences in serum proteomes between $A$. vasorum-infected foxes and dogs. So far, no blood analyses have been carried out using naturally infected wild foxes. Two studies were conducted with $A$. vasorum experimentally infected foxes previously, focused on differences in larval excretion, worm burden, clinical and haematological alterations in juvenile and adult animals following single and repeated challenge infections [26,27]. Standard haematology, blood chemistry and coagulation analysis performed in one of these studies revealed eosinophilia, increased D-dimers and decreased platelets upon infection [26]. This prior work relied on fox samples of which only eosinophil counts were determined [27].

Our findings generated by LC-MS demonstrated that a high number of proteins show altered levels in infected foxes, with numbers increasing as infection progresses. The number of increased or decreased proteins in foxes (276) was twice as high as in infected dogs (139 proteins) [32]. Several proteins associated with inflammatory and immune response and proteins involved in coagulation were either increased or decreased in foxes, compared to the established pre-infection baseline. To further validate the obtained fox data, targeted protein quantification by Parallel Reaction Monitoring (PRM), as previously conducted for dog serum samples [32], could be conducted.

The protein that increased the most throughout experimental infection in foxes was bone marrow proteoglycan, also known as eosinophil major basic protein. This protein originates from eosinophils, key immune cells in the host defence against helminths [34]. 
Bone marrow proteoglycan acts as a cytotoxin and helminthotoxin; it causes activation and degranulation of neutrophils in a non-cytotoxic fashion [35,36], which is reflected in the enriched biological processes "neutrophil mediated immunity", "neutrophil activation involved in immune response", and "neutrophil degranulation". Bone marrow proteoglycan further leads to activation and aggregation of platelets [37], contributing to the enriched pathway "platelet degranulation". Bone marrow proteoglycan is usually released at the site where it is needed and can cause both a toxic and proinflammatory reaction [35]. Therefore, the 22- to 26-fold increase in this protein in foxes throughout the course of the infection indicates a strong innate immune response against $A$. vasorum proceeding from eosinophils and reflects findings of eosinophilia in experimentally infected foxes: eosinophilia has been reported in experimentally infected juvenile and adult foxes starting 3 and 4 weeks post infection and represented the only increased white blood cells upon infection [26]. In foxes from the current study, eosinophilia was shown to be present from $\mathrm{d} 35$ onwards, remaining until the end of the study (22 weeks after infection) [27]. In contrast, in experimentally infected dogs, eosinophilia was absent or mild until 90 days after infection [19], and was occasionally reported in naturally infected dogs [18,38]. Accordingly, bone marrow proteoglycan was not increased in serum used for quantitative proteomic analysis of experimentally infected dogs [32]. These findings, combined with clinical signs predominantly occurring in dogs, may indicate that this protein favours subclinical disease in foxes. Both dogs and foxes, however, manifest severe lung pathologies upon infection, suggesting that bone marrow proteoglycan does not protect from lung damage. The data may also suggest that foxes develop a more appropriate innate immune response to $A$. vasorum infection compared to dogs, leading them to better cope with infection, despite persisting infections [27]. Dogs, in turn, apparently fail to mount an appropriate and effective eosinophil response [19,32].

Further highly increased proteins at chronic stages of infection in both host species were chitinase-3-like protein 1 and pulmonary surfactant-associated protein B. Chitinase3-like protein 1 is released by different cells, including neutrophils and macrophages. Inflammation induces an increase in chitinase-3-like protein 1 in the lung, where it is described to play a role in antibacterial responses and Th2 immune response, and increases mucin expression [39]. It has also been described to have antiparasitic properties through IL-17-mediated neutrophil recruitment as a response to nematode migration through lung tissue, leading to further lung damage [40].

Pulmonary surfactant-associated protein B is responsible for reducing the air surface tension in the lung alveoli, modulates the immune response and has some antimicrobial effects [41]. The increase in both of these proteins further reflects the immune and inflammatory response of the fox to A. vasorum infection. Indeed, L1, which hatch in pulmonary capillaries, migrate into the lung alveoli causing tissue damage, and lead to verminous pneumonia [19]. This process contributes to inflammation and likely induces an increase in both chitinase-3-like protein 1 and pulmonary surfactant-associated protein B. Both proteins were also detected at increased levels in A. vasorum-infected dogs and, therefore, were proteins with the strongest abundance increase upon infection in both species. This suggests that both dogs and foxes experience lung inflammation and damage to a comparable extent, which is also reflected in comparable lung pathologies in naturally and experimentally infected animals: consolidated lungs, nodule formation, discoloration, lung fibrosis and/or foci of chronic thrombosis, most pronounced at the margins of the lung lobes, are described for both dogs and foxes [5,19,28,29].

A few proteins that may influence coagulation or interact with endothelium, e.g., fibrinogen, thrombospondin 1 , or fibulin 5, were increased in foxes. Their increase is mostly associated with inflammation $[42,43]$. Several coagulation factors and proteins involved in the coagulation cascade, such as vitamin K-dependent protein C, coagulation factor XIII A chain, coagulation factor IX, and coagulation factor $X$, however, were among decreased proteins in foxes, although none of them were decreased further than $\log 2 \mathrm{FC}<-2$. Decreased abundance of coagulation proteins may represent a compensatory mechanism 
to increased abundance of proteins that may directly or indirectly activate coagulation. Interestingly, coagulation factor XIII A chain was decreased in foxes and, accordingly, its $B$ chain in dogs [32]. Coagulation factor XIII stabilizes fibrin clots, and its deficiency can cause haemorrhages [44]. Mutations in the gene encoding A chains cause reduced fibrin clot thickness and result in clots more prone to degradation, eventually leading to increased bleeding tendencies [45]. This has, however, never been observed in foxes. Fibrinogen chains and thrombospondin 1 levels were increased in foxes but decreased in dogs. Both analyses in dogs and foxes were based on serum and not plasma samples, which generally should be depleted of fibrinogen and most coagulation factors or may only contain trace amounts. This may limit the interpretation of findings on some coagulation proteins. In addition, variations at different time points could be potentially due to differing clotting efficiency or clotting time before centrifugation or handling of the samples, which may have been slightly inconsistent. The same needs to be kept in mind when comparing altered coagulation components in dogs and foxes: differing blood collection systems may also have had an influence on clotting efficiency. Further, proteomes and genomes of both species are of different quality, and diverging annotations may have influenced the functional characterization of some proteins. Nonetheless, we observed that several proteins relevant for coagulation were either increased or decreased in foxes, leading to the enrichment of several coagulation pathways represented from both increased and decreased protein fractions, e.g., "platelet degranulation", "platelet activation, signalling and aggregation", "formation of fibrin clot (clotting cascade)", "common pathway of fibrin clot formation", and "haemostasis". We hypothesize that A. vasorum infection may lead to both activation and suppression of coagulation in foxes, either through alterations induced by the parasite or through the host response. Indeed, blood dwelling parasites are known to interfere with the host coagulation in a balanced manner to neither induce nor suppress coagulation, which guarantees their long-term survival in the host [46].

Only one mannan binding lectin serine peptidase was increased in foxes, whereas several mannan binding lectin serine peptidases were decreased in dogs. Therefore, the complement cascade was among putative impaired pathways in dogs [32], which accordingly was not observed in foxes, indicating less involvement of the complement system in infected foxes. Another difference between the two canid species was the increase in Ig-like domain-containing proteins in dogs only, suggesting lower levels of circulating antibodies upon infection in foxes compared to dogs. This is in accordance with highly variable serum antibody responses among foxes and decreasing antibody levels within 7 weeks after infection (or repeated infections), despite high worm burdens in most individuals $[26,27,47]$. Declining levels of serum antibodies were observed in an earlier study in experimentally infected foxes [26]. In contrast, a strong and persisting antibody response was detected in dogs [48]. This may suggest that foxes develop tolerance to A. vasorum, but not without experiencing serum protein alterations. Particularly juvenile animals with high worm burdens showed more pronounced pathophysiological changes, especially regarding the coagulation parameter D-dimer, which is an indicator of active coagulation and fibrinolysis [26]. Seven out of eight foxes in the study presented here were juveniles. Naturally infected young foxes were previously found to have more severe lung pathologies as compared to adult animals [49]. The observed pathologies, however, were not reflected in a corresponding clinical picture, since no clinical signs were observed in experimentally infected foxes [26,27], and clinical signs have been very rarely reported in naturally infected wild foxes [24,25]. The apparent absence of clinical signs in foxes can most likely be explained by the intrinsic characteristics of wild animals: foxes are generally not held as pets or farm animals and, therefore, not monitored; in addition, they are known to have a much shorter life span [50,51], implying lower chances of establishment of chronic infections. But even though coagulopathies have never been observed in foxes, our findings suggest that the parasite may cause health impairment in foxes: an infection may shorten their life expectancy and/or increase their odds of succumbing to other diseases or accidents. 
For the present study, farmed foxes bred for years in captivity and unexposed to A. vasorum were used. The used infective dose in foxes did not lead to clinical illness, despite proven constant larval excretion and corresponding worm burdens. Their strong eosinophil response and increased levels of bone marrow proteoglycan in sera may have contributed to the absence of clinical disease development. In addition, the variable individual antibody response without persistence of specific antibodies explains their susceptibility to reinfection and may indicate a fox-specific immunological response. Dogs in comparison mostly did not mount an eosinophil response and, accordingly, bone marrow proteoglycan levels were not increased in experimentally infected dogs. Experimentally and naturally infected dogs suffered from severe disease upon infection, despite persisting antibodies. Our findings, therefore, imply that $A$. vasorum is likely more adapted to foxes, and that foxes seem to cope better with the infection. This difference may be even more pronounced in wild foxes as compared to foxes farmed for generations. Therefore, under natural settings, the more adequate immune response of foxes could facilitate fox survival and, therefore, the spread of $A$. vasorum to larger areas, further supporting their importance as wildlife reservoir hosts.

\section{Materials and Methods}

\subsection{Sera from Foxes Experimentally Inoculated with A. vasorum}

Sera were taken from 1 adult and 7 juvenile female foxes experimentally infected with A. vasorum originating from a previously conducted experiment [27]. Briefly, foxes were inoculated with $100 \mathrm{~A}$. vasorum L3, which were obtained from experimentally infected Biomphalaria glabrata snails. The isolate originated from an infected dog and had been passaged once in a fox. Well-being and potential clinical signs were monitored daily, and foxes were examined more thoroughly at blood sampling and before necropsy. Blood samples were obtained from the jugular veins (vacutainer-system SST tubes with clot activator) the day of inoculation and $35,49,63,70,84,91,98,112,119$, and 140 days post inoculation (dpi), and on the day of necropsy ( $84 \mathrm{dpi}, n=3 ; 154 \mathrm{dpi}, n=5$ ). Four to $8 \mathrm{~h}$ after sampling, sera were isolated by centrifugation $(1380 \times g, 10 \mathrm{~min})$ and kept at $-20{ }^{\circ} \mathrm{C}$ until use. Differences between the euthanasia dates were related to the experimental design of the previously performed study. Detailed information on the experimental procedures, larval shedding, worm burden after necropsy, and haematology is available in Woolsey et al. [27]. Briefly, serum samples used for this study were from foxes with worm burden ranging from 18 to 61 (mean 55, with one out layer above 100). Larval shedding one week before necropsy ranged from 2 to 2770 larvae per gram faeces (LPG) (mean 1375 LPG). The study was conducted under the Danish experimental animal licence no. 2005/561-1060.

Time points were selected in analogy to Tritten et al. [32] in order to obtain serum profiles before infection (day 0; d0), during prepatency (day $35 \mathrm{dpi}$; d35), during patency (day 84 dpi; d84), and at a time point of chronic infection (day $154 \mathrm{dpi}$; d154, from 5 juvenile foxes only). For each fox, d0 represented the baseline time point. Sera samples had been stored at $-20{ }^{\circ} \mathrm{C}$ for 13 years prior to the use for this study.

\subsection{Serum Sample Preparation}

From each fox serum sample, $200 \mu \mathrm{L}$ was prepared as described by Tritten et al. [32]. Serum samples were processed using the ProteoMiner small capacity kit (Bio-Rad) for protein enrichment according to the manufacturer's instructions. Proteins were then precipitated using a trichloroacetic acid (TCA) protocol. Briefly, protein eluates were diluted in $\mathrm{dH}_{2} \mathrm{O}$, sodium deoxycholate $0.15 \%$, and TCA $72 \%$, incubated and centrifuged. Pellets were washed three times with ice-cold acetone and centrifuged. Samples were air-dried and resuspended in $50 \mu \mathrm{L} \mathrm{4 \%} \mathrm{SDS,} \mathrm{Tris-} \mathrm{HCl} 0.1 \mathrm{M}, \mathrm{pH}=7.6,0.1 \mathrm{M}$ DTT and heated at $95{ }^{\circ} \mathrm{C}$ for $5 \mathrm{~min}$. Protein content was measured by a Qubit protein assay (Thermo Fisher Scientific). Next, $30 \mu \mathrm{g}$ of protein were further processed by filter-aided sample preparation [52]: samples were mixed with $8 \mathrm{M}$ urea/100 mM Tris- $\mathrm{HCl} \mathrm{pH}=8.2$, loaded onto Microcon 30 filter 
units (Millipore) and centrifuged. Samples were washed with urea buffer and treated with $0.05 \mathrm{M}$ iodoacetamide (IAA), incubated and centrifuged. This was followed by three urea buffer washes and two $0.5 \mathrm{M} \mathrm{NaCl}$ washes. Then, $0.05 \mathrm{M}$ triethylammoniumbicarbonate and sequencing grade modified trypsin (Promega, V5113) were added and samples were incubated overnight. Samples were centrifuged and trifluoroacetic acid (TFA) 5\% was added to adjust $\mathrm{pH}$. Samples were then desalted using C18 stage tips [53]: stage tips were washed and equilibrated with 100\% methanol, 60\% acetonitrile (ACN) $/ 0.1 \%$ TFA and 3\% ACN $/ 0.1 \%$ TFA. Samples were treated with 3\% ACN $/ 0.1 \%$ TFA, loaded onto columns and centrifuged. They were then washed twice with 3\% ACN $/ 0.1 \%$ TFA and eluted with $60 \%$ ACN $/ 0.1 \%$ TFA. Samples were dried to completeness using a speed-vac and resuspended in $3 \% \mathrm{ACN} / 0.1 \%$ formic acid (FA).

\subsection{LC-MS Analysis}

Fox serum peptide samples were diluted in $3 \% \mathrm{ACN}, 0.1 \%$ FA to $1 \mu \mathrm{g} / \mu \mathrm{L}$ and retention time normalization peptides (iRT, Biognosys) added (1:20). Samples were analysed in random order by data independent analysis (DIA) on a hybrid quadrupole-Orbitrap mass spectrometer (Q Exactive HF, Thermo Fisher Scientific), which was operated in line with an Acquity UHPLC M-class system (Waters) with a nanoEase M/Z Symmetry C18 trap column (100 A, $5 \mu \mathrm{m}, 180 \mu \mathrm{m} \times 20 \mathrm{~mm}$, Waters) and a nanoEase M/Z HSS C18 T3 analytical column (100 A, $1.8 \mu \mathrm{m}, 75 \mu \mathrm{m} \times 250 \mathrm{~mm}$ Column, Waters). Then, $1 \mu \mathrm{L}$ per sample was eluted and run on a linear gradient from 5\% to $32 \% 0.1 \%$ FA in ACN over 120 min at $300 \mathrm{nl} / \mathrm{min}$. A nano electrospray ionization (ESI) source (Digital PicoView 565, O/N: DPV550-565, New Objective, Woburn, MA) and a $10 \mu \mathrm{m}$ fused-silica spray tip emitter (New Objective, PN) ionized the peptides. MS1 scans covered 350-1800 m/z and were recorded in centroid mode. They were recorded in positive polarity, with a resolution of 60,000 and automated gain control (AGC) with a target value of $3 \times 10^{6}$. The maximum injection time (maxIT) was $200 \mathrm{~ms}$. MS1 scans were followed by 35 DIA scans in positive polarity with 30,000 resolution. The AGC target was $1 \times 10^{6}$ and the maxIT $55 \mathrm{~ms}$. DIA scans covered a mass range of $400-1100 \mathrm{~m} / \mathrm{z}$ in $20 \mathrm{~m} / \mathrm{z}$ isolation windows and were recorded in centroid mode. Fixed first mass was set to $100 \mathrm{~m} / \mathrm{z}$ and isolated precursors were fragmented with higher-energy collisional dissociation (HCD) at a normalized collision energy (NCE) of 28.

Spectronaut (v. 13; Biognosys) was used for label-free protein quantification. DirectDIA analysis based on the UniProt proteome of Vulpes vulpes (UP000286640, accessed: 29 June 2020), Angiostrongylus costaricensis (UP000050601, accessed: 9 January 2019), and Angiostrongylus cantonensis (UP000035642; accessed: 9 January 2019) was performed. Angiostrongylus costaricensis and $A$. cantonensis represented the two most closely related species to $A$. vasorum with available reference proteomes. These proteomes were included to identify circulating parasite proteins in serum samples. BGS factory settings were used for analysis. These settings included tryptic specificity, allowing two missed cleavages, carbamidomethyl as a fixed cysteine modification, and oxidation of methionine and protein N-terminal acetylation as variable modifications. Protein groups identified by a single peptide sequence were excluded. Single hit definition was defined by stripped sequence. FDR was set to $1 \%$ for peptide spectrum matches and proteins. The raw mass spectrometry data and Spectronaut outputs have been deposited to the ProteomeXchange Consortium via the PRIDE [54] partner repository (dataset identifier PXD028312).

\subsection{Data Analysis}

Data were exported from Spectronaut and analysed using the MSStats $\mathrm{R}$ package (v. 4.0.3) [55] for statistical relative quantification and significance analysis, as described by Tritten et al. [32]. Briefly, data were $\log 2$ transformed, normalized by equalizeMedians, and summarized by Tukey's median polish. The model took repeated sampling from the same fox into account. Cut-offs for significant protein increase or decrease were defined by an adjusted $p$-value $\leq 0.05$ and $\log 2 \mathrm{FC} \geq 1$, or $\leq-1$. For further analysis, specific human orthologues were retrieved via NCBI blastp for increased or decreased proteins, 
as defined by the cut-offs, since foxes are not well characterized. E values $<1 \times 10^{-20}$ were considered high-quality matches. Orthologues were converted to gene symbols using DAVID (v. 6.8) [56] and analysed with Enrichr [57] for gene set enrichment analysis to obtain pathway and gene ontology terms.

\subsection{Qualitative Comparison of Serum Alterations of Experimentally Infected Foxes and Dogs}

Fox results were qualitatively compared to results obtained from dog samples from a previous study [32] in order to compare host-specific responses in these two animal species. Therefore, the same methods and similar time points were used to analyse serum samples of $A$. vasorum experimentally infected dogs and foxes. Briefly, serum samples (stored for 9 years) of $8 A$. vasorum experimentally infected dogs from 3 time points were analysed: 7 days before infection (d-7), 34 days (d34) and 75 days (d75) after inoculation. From two dogs, two further time points were available and analysed (104 and $230 \mathrm{dpi}$; d104 and d230). Samples were enriched, precipitated, digested and analysed by LC-MS (DIA). Data were analysed in Proteome Discoverer and Spectronaut and further analysed using MSStats and STRING [32]. Protein abundance increase and decrease in fox time point comparisons were compared to the ones of dogs: d35 vs. d0 of foxes was compared to d34 vs. d-7 of dogs, foxes' d84 vs. d0 was compared to d75 vs. d-7 in dogs, and d154 vs. d0 of foxes compared to both d104 and d230 vs. d-7 obtained from two dogs.

\section{Conclusions}

Serum proteins involved in the immune and inflammatory response are strongly increased upon experimental $A$. vasorum infection in farm foxes. Several altered proteins, including both increased and decreased levels of proteins interfering with coagulation, led to enriched coagulation pathways, suggesting simultaneous activation and suppression of blood clotting in foxes, either induced through the parasite itself or the host immune response. Considering the overall changes upon infection in foxes, the observed serum alterations are indicative of some disease development in foxes, although no clinical manifestations were observed in the animals of the present study. The qualitative comparison to dog serum data suggests some parallel serum alterations in foxes, encompassing abundance increase in proteins involved in inflammation or immune response and decrease in coagulation proteins. However, a strong increase in bone marrow proteoglycan was only observed in foxes, suggesting that foxes develop an increased innate immune response upon $A$. vasorum infection compared to dogs. This may imply that foxes are more tolerant to $A$. vasorum infection compared to dogs, reflecting a longer evolutionary host-parasite adaptation in foxes, and also supporting their important role as reservoir hosts under field conditions.

Supplementary Materials: The following are available online at https://www.mdpi.com/article/10 .3390 / pathogens10111513/s1. Supplementary Figure S1 displays a heat map of identified proteins from all examined fox serum samples. Supplementary Table S1 contains a detailed list with all significant increased or decreased fox serum proteins of all time point comparisons. Supplementary Table S2 contains all significant biological processes and enriched pathways obtained from either increased or decreased proteins.

Author Contributions: N.G.-G., L.T. and T.K. conceived the study; N.G.-G. carried out the laboratory experiments; N.G.-G., L.T. and T.K. analysed data; L.T. and M.S. supervised the project; T.K. was an advisor of the project; P.W., C.M.O.K. and S.M.T. planned and carried out the experimental study and provided the serum samples; N.G.-G. wrote the manuscript with support from L.T., M.S. and T.K. All authors have read and agreed to the published version of the manuscript.

Funding: We would like to thank the 'Forschungskredit' from the University of Zurich, Switzerland and Bayer Vital GmbH, Business Unit Animal Health, Germany for financial support to N.G.-G. during her PhD studies. Part of this study was funded by The Danish National Research Council (SJVF), grant No. 23-04-0202. 
Institutional Review Board Statement: The experimental fox study was approved by the Experimental Animal Unit, University of Copenhagen according to FELASA guidelines and recommendations and performed under the Danish experimental animal licence no. 2005/561-1060, Ministry of Food, Agriculture and Fisheries of Denmark. The study was performed prior to the establishment of a research ethics committee (institutional review board) at University of Copenhagen in 2016.

Data Availability Statement: The raw mass spectrometry data and Spectronaut outputs have been deposited to the ProteomeXchange Consortium via the PRIDE [54] partner repository (dataset identifier PXD028312). The datasets supporting the results and conclusions of this article are included within the article and its supplementary files. Dog serum data used for comparison of fox serum alteration to data from experimentally infected dogs are available from Tritten et al. [32] at https: / / doi.org/10.1038/s41598-020-79459-9 (including supplementary information). The R code (MSstats) and further data are available from the corresponding authors upon request.

Acknowledgments: We would like to thank Sina Hasler for her help with laboratory procedures. Figure 2 was created with BioRender.com.

Conflicts of Interest: The authors declare no conflict of interest. The funders had no role in the design of the study; in the collection, analyses, or interpretation of data; in the writing of the manuscript, or in the decision to publish the results.

\section{References}

1. Guilhon, J.; Cens, B. Angiostrongylus vasorum (Baillet, 1866): Étude biologique et morphologique. Ann. Parasitol. Hum. Comp. 1973, 48, 567-596. [CrossRef]

2. Koch, J.; Willesen, J.L. Canine pulmonary angiostrongylosis: An update. Vet. J. 2009, 179, 348-359. [CrossRef]

3. Conboy, G.A. Canine angiostrongylosis: The French heartworm: An emerging threat in North America. Vet. Parasitol. 2011, 176, 382-389. [CrossRef] [PubMed]

4. $\quad$ Penagos-Tabares, F.; Lange, M.K.; Chaparro-Gutiérrez, J.J.; Taubert, A.; Hermosilla, C. Angiostrongylus vasorum and Aelurostrongylus abstrusus: Neglected and underestimated parasites in South America. Parasite Vector 2018, 11, 208. [CrossRef] [PubMed]

5. Gillis-Germitsch, N.; Tritten, L.; Hegglin, D.; Deplazes, P.; Schnyder, M. Conquering Switzerland: The emergence of Angiostrongylus vasorum in foxes over three decades and its rapid regional increase in prevalence contrast with the stable occurrence of lungworms. Parasitology 2020, 147, 1071-1079. [CrossRef] [PubMed]

6. Taylor, C.S.; Garcia Gato, R.; Learmount, J.; Aziz, N.A.; Montgomery, C.; Rose, H.; Coulthwaite, C.L.; McGarry, J.W.; Forman, D.W.; Allen, S.; et al. Increased prevalence and geographic spread of the cardiopulmonary nematode Angiostrongylus vasorum in fox populations in Great Britain. Parasitology 2015, 142, 1190-1195. [CrossRef]

7. Maksimov, P.; Hermosilla, C.; Taubert, A.; Staubach, C.; Sauter-Louis, C.; Conraths, F.J.; Vrhovec, M.G.; Pantchev, N. GISsupported epidemiological analysis on canine Angiostrongylus vasorum and Crenosoma vulpis infections in Germany. Parasite Vector 2017, 10, 108. [CrossRef]

8. Hurnikova, Z.; Miterpakova, M.; Mandelik, R. First autochthonous case of canine Angiostrongylus vasorum in Slovakia. Parasitol. Res. 2013, 112, 3505-3508. [CrossRef]

9. Jolly, S.; Poncelet, L.; Lempereur, L.; Caron, Y.; Bayrou, C.; Cassart, D.; Grimm, F.; Losson, B. First report of a fatal autochthonous canine Angiostrongylus vasorum infection in Belgium. Parasitol. Int. 2015, 64, 97-99. [CrossRef]

10. Traversa, D.; Di Cesare, A.; Meloni, S.; di Regalbono, A.F.; Milillo, P.; Pampurini, F.; Venco, L. Canine angiostrongylosis in Italy: Occurrence of Angiostrongylus vasorum in dogs with compatible clinical pictures. Parasitol. Res. 2013, 112, 2473-2480. [CrossRef]

11. Bourque, A.; Whitney, H.; Conboy, G. Angiostrongylus vasorum infection in a coyote (Canis latrans) from Newfoundland and Labrador, Canada. J. Wildl. Dis. 2005, 41, 816-819. [CrossRef]

12. Duarte, F.; Vieira, F.; Louzada, G.; Bessa, E.; Souzalima, S. Occurrence Angiostrongylus vasorum (Baillet, 1866) (Nematoda, Angiostrongylidae) in Cerdocyon thous Linnaeus, 1766 (Carnivora, Canidae) in Minas Gerais State Brazil. Arq. Bras. Med. Vet. Zootec. 2007, 59, 1086-1088. [CrossRef]

13. Lima, W.; Guimaraes, M.; Lemos, I. Research Note Occurrence of Angiostrongylus vasorum in the lungs of the Brazilian fox Dusicyon vetulus. J. Helminthol. 1994, 68, 87. [CrossRef]

14. Segovia, J.; Torres, J.; Miquel, J.; Llaneza, L.; Feliu, C. Helminths in the wolf, Canis lupus, from north-western Spain. J. Helminthol. 2001, 75, 183-192. [CrossRef] [PubMed]

15. Patterson-Kane, J.C.; Gibbons, L.M.; Jefferies, R.; Morgan, E.R.; Wenzlow, N.; Redrobe, S.P. Pneumonia from Angiostrongylus vasorum infection in a red panda (Ailurus fulgens fulgens). J. Vet. Diagn. Investig. 2009, 21, 270-273. [CrossRef]

16. Torres, J.; Miquel, J.; Motjé, M. Helminth parasites of the eurasian badger (Meles meles L.) in Spain: A biogeographic approach. Parasitol. Res. 2001, 87, 259-263. [CrossRef]

17. Gillis-Germitsch, N.; Manser, M.B.; Hilbe, M.; Schnyder, M. Meerkats (Suricata suricatta), a new definitive host of the canid nematode Angiostrongylus vasorum. Int. J. Parasitol. Parasites Wildl. 2017, 6, 349-353. [CrossRef] [PubMed] 
18. Chapman, P.S.; Boag, A.K.; Guitian, J.; Boswood, A. Angiostrongylus vasorum infection in 23 dogs (1999-2002). J. Small Anim. Pract. 2004, 45, 435-440. [CrossRef] [PubMed]

19. Schnyder, M.; Fahrion, A.; Riond, B.; Ossent, P.; Webster, P.; Kranjc, A.; Glaus, T.; Deplazes, P. Clinical, laboratory and pathological findings in dogs experimentally infected with Angiostrongylus vasorum. Parasitol. Res. 2010, 107, 1471-1480. [CrossRef]

20. Glaus, T.M.; Sigrist, N.; Hofer-Inteeworn, N.; Kuemmerle-Fraune, C.; Mueller, C.; Geissweid, K.; Beckmann, K.; Wenger, M.; Novo Matos, J. Unexplained bleeding as primary clinical complaint in dogs infected with Angiostrongylus vasorum. Schweiz. Arch. Tierheilkd. 2016, 158, 701-709. [CrossRef]

21. Adamantos, S.; Waters, S.; Boag, A. Coagulation status in dogs with naturally occurring Angiostrongylus vasorum infection. J. Small Anim. Pract. 2015, 56, 485-490. [CrossRef] [PubMed]

22. Sigrist, N.E.; Hofer-Inteeworn, N.; Jud Schefer, R.; Kuemmerle-Fraune, C.; Schnyder, M.; Kutter, A.P.N. Hyperfibrinolysis and hypofibrinogenemia diagnosed with rotational thromboelastometry in dogs naturally infected with Angiostrongylus vasorum. J. Vet. Intern. Med. 2017, 31, 1091-1099. [CrossRef]

23. Gredal, H.; Willesen, J.L.; Jensen, H.E.; Nielsen, O.L.; Kristensen, A.T.; Koch, J.; Kirk, R.K.; Pors, S.E.; Skerritt, G.C.; Berendt, M. Acute neurological signs as the predominant clinical manifestation in four dogs with Angiostrongylus vasorum infections in Denmark. Act. Vet. Scand. 2011, 53, 43. [CrossRef]

24. Simpson, V.R. Angiostrongylus vasorum infection in foxes (Vulpes vulpes) in Cornwall. Vet. Rec. 1996, 139, 443-445. [CrossRef]

25. Philbey, A.W.; Delgado, D. Detection of Angiostrongylus vasorum in red foxes in Scotland. Vet. Rec. 2013, 173. [CrossRef]

26. Webster, P.; Monrad, J.; Kapel, C.M.O.; Kristensen, A.T.; Jensen, A.L.; Thamsborg, S.M. The effect of host age and inoculation dose on infection dynamics of Angiostrongylus vasorum in red foxes (Vulpes vulpes). Parasite Vector 2017, 10, 4. [CrossRef] [PubMed]

27. Woolsey, I.D.; Webster, P.; Thamsborg, S.; Schnyder, M.; Monrad, J.; Kapel, C.M.O. Repeated inoculations with the lung and heartworm nematode Angiostrongylus vasorum result in increasing larval excretion and worm burden in the red fox (Vulpes vulpes). Int. J. Parasitol. Parasites Wildl. 2017, 6, 139-145. [CrossRef] [PubMed]

28. Poli, A.; Arispici, M.; Mancianti, F.; Abramo, F. Pathology of naturally acquired Angiostrongylus vasorum infection in the red fox (Vulpes vulpes). Angew. Parasitol. 1991, 32, 121-126.

29. Bourque, A.C.; Conboy, G.; Miller, L.M.; Whitney, H. Pathological findings in dogs naturally infected with Angiostrongylus vasorum in Newfoundland and Labrador, Canada. J. Vet. Diagn. Investig. 2008, 20, 11-20. [CrossRef]

30. McEvoy, F.J.; Buelund, L.; Strathe, A.B.; Willesen, J.L.; Koch, J.; Webster, P.I.A.; Hørlyck, L.; Svalastoga, E. Quantitative computed tomography evaluation of pulmonary disease. Vet. Radiol. Ultrasound 2009, 50, 47-51. [CrossRef]

31. Dennler, M.; Makara, M.; Kranjc, A.; Schnyder, M.; Ossent, P.; Deplazes, P.; Ohlerth, S.; Glaus, T.M. Thoracic computed tomography findings in dogs experimentally infected with Angiostrongylus vasorum. Vet. Radiol. Ultrasound 2011, 52, 289-294. [CrossRef] [PubMed]

32. Tritten, L.; Gillis-Germitsch, N.; Kockmann, T.; Schnyder, M. Quantitative proteomics analysis of Angiostrongylus vasorum-induced alterations in dog serum sheds light on the pathogenesis of canine angiostrongylosis. Sci. Rep. 2021, 11, 283. [CrossRef] [PubMed]

33. Cury, M.C.; Lima, W.S.; Guimarães, M.P.; Carvalho, M.G. Hematological and coagulation profiles in dogs experimentally infected with Angiostrongylus vasorum (Baillet, 1866). Vet. Parasitol. 2002, 104, 139-149. [CrossRef]

34. Huang, L.; Appleton, J.A. Eosinophils in Helminth Infection: Defenders and Dupes. Trends Parasitol. 2016, 32, 798-807. [CrossRef]

35. Popken-Harris, P.; Checkel, J.; Loegering, D.; Madden, B.; Springett, M.; Kephart, G.; Gleich, G.J. Regulation and processing of a precursor form of eosinophil granule major basic protein (ProMBP) in differentiating eosinophils. Blood 1998, 92, 623-631. [CrossRef]

36. Thomas, L.L.; Haskell, M.D.; Sarmiento, E.U.; Bilimoria, Y. Distinguishing features of basophil and neutrophil activation by major basic protein. J. Allergy Clin. Immunol. 1994, 94, 1171-1176. [CrossRef]

37. Rohrbach, M.S.; Wheatley, C.; Slifman, N.; Gleich, G. Activation of platelets by eosinophil granule proteins. J. Exp. Med. 1990, 172, 1271-1274. [CrossRef]

38. Willesen, J.L.; Jensen, A.L.; Kristensen, A.T.; Koch, J. Haematological and biochemical changes in dogs naturally infected with Angiostrongylus vasorum before and after treatment. Vet. J. 2009, 180, 106-111. [CrossRef]

39. Zhao, T.; Su, Z.; Li, Y.; Zhang, X.; You, Q. Chitinase-3 like-protein-1 function and its role in diseases. Signal. Transduct. Target. Ther. 2020, 5, 201. [CrossRef]

40. Sutherland, T.E.; Logan, N.; Rückerl, D.; Humbles, A.A.; Allan, S.M.; Papayannopoulos, V.; Stockinger, B.; Maizels, R.M.; Allen, J.E. Chitinase-like proteins promote IL-17-mediated neutrophilia in a tradeoff between nematode killing and host damage. Nat. Immunol. 2014, 15, 1116-1125. [CrossRef]

41. Han, S.; Mallampalli, R.K. The role of surfactant in lung disease and host defense against pulmonary infections. Ann. Am. Thorac. Soc. 2015, 12, 765-774. [CrossRef]

42. Lawler, J. The functions of thrombospondin-1 and-2. Curr. Opin. Cell Biol. 2000, 12, 634-640. [CrossRef]

43. Fuller, G.M.; Zhang, Z. Transcriptional Control Mechanism of Fibrinogen Gene Expression. Ann. N. Y. Acad. Sci. 2001, 936, 469-479. [CrossRef]

44. Yan, M.T.S.; Rydz, N.; Goodyear, D.; Sholzberg, M. Acquired factor XIII deficiency: A review. Transfus. Apher. Sci. 2018, 57, 724-730. [CrossRef] 
45. Thomas, A.; Biswas, A.; Dodt, J.; Philippou, H.; Hethershaw, E.; Ensikat, H.J.; Ivaskevicius, V.; Oldenburg, J. Coagulation factor XIIIA subunit missense mutations affect structure and function at the various steps of Factor XIII action. Hum. Mutat. 2016, 37, 1030-1041. [CrossRef]

46. Mebius, M.M.; van Genderen, P.J.J.; Urbanus, R.T.; Tielens, A.G.M.; de Groot, P.G.; van Hellemond, J.J. Interference with the host haemostatic system by Schistosomes. PLoS Pathog. 2013, 9, e1003781. [CrossRef] [PubMed]

47. Gillis-Germitsch, N.; Kapel, C.M.O.; Thamsborg, S.M.; Deplazes, P.; Schnyder, M. Host-specific serological response to Angiostrongylus vasorum infection in red foxes (Vulpes vulpes): Implications for parasite epidemiology. Parasitology 2017, 144, 1144-1153. [CrossRef]

48. Schucan, A.; Schnyder, M.; Tanner, I.; Barutzki, D.; Traversa, D.; Deplazes, P. Detection of specific antibodies in dogs infected with Angiostrongylus vasorum. Vet. Parasitol. 2012, 185, 216-224. [CrossRef]

49. Eleni, C.; Grifoni, G.; Di Egidio, A.; Meoli, R.; De Liberato, C. Pathological findings of Angiostrongylus vasorum infection in red foxes (Vulpes vulpes) from Central Italy, with the first report of a disseminated infection in this host species. Parasitol. Res. 2014, 113, 1247-1250. [CrossRef]

50. Fischer, C.; Reperant, L.; Weber, J.; Hegglin, D.; Deplazes, P. Echinococcus multilocularis infections of rural, residential and urban foxes (Vulpes vulpes) in the canton of Geneva, Switzerland. Parasite 2005, 12, 339-346. [CrossRef] [PubMed]

51. Coman, B. The age structure of a sample of red foxes (Vulpes vulpes) taken by hunters in Victoria. Wildl. Res. 1988, 15, 223-229. [CrossRef]

52. Wiśniewski, J.R.; Zougman, A.; Nagaraj, N.; Mann, M. Universal sample preparation method for proteome analysis. Nat. Methods 2009, 6, 359-362. [CrossRef] [PubMed]

53. Rappsilber, J.; Ishihama, Y.; Mann, M. Stop and go extraction tips for matrix-assisted laser desorption/ionization, nanoelectrospray, and LC/MS sample pretreatment in proteomics. Anal. Chem. 2003, 75, 663-670. [CrossRef]

54. Vizcaíno, J.A.; Deutsch, E.W.; Wang, R.; Csordas, A.; Reisinger, F.; Rios, D.; Dianes, J.A.; Sun, Z.; Farrah, T.; Bandeira, N. ProteomeXchange provides globally coordinated proteomics data submission and dissemination. Nat. Biotechnol. 2014, 32, $223-226$. [CrossRef]

55. Choi, M.; Chang, C.-Y.; Clough, T.; Broudy, D.; Killeen, T.; MacLean, B.; Vitek, O. MSstats: An R package for statistical analysis of quantitative mass spectrometry-based proteomic experiments. Bioinformatics 2014, 30, 2524-2526. [CrossRef] [PubMed]

56. Huang, D.W.; Sherman, B.T.; Lempicki, R.A. Systematic and integrative analysis of large gene lists using DAVID bioinformatics resources. Nat. Protoc. 2009, 4, 44-57. [CrossRef] [PubMed]

57. Kuleshov, M.V.; Jones, M.R.; Rouillard, A.D.; Fernandez, N.F.; Duan, Q.; Wang, Z.; Koplev, S.; Jenkins, S.L.; Jagodnik, K.M.; Lachmann, A.; et al. Enrichr: A comprehensive gene set enrichment analysis web server 2016 update. Nucleic Acids Res. 2016, 44, W90-W97. [CrossRef] 